\title{
7. REE, Ba, AND Sr ABUNDANCES AND Sr, Nd, AND Ce ISOTOPIC RATIOS IN HOLE 504B BASALTS, ODP LEG 111, COSTA RICA RIFT ${ }^{1}$
}

\author{
Hiroshi Shimizu, Kouji Mori, and Akimasa Masuda²
}

\begin{abstract}
Abundances of rare earth elements (REE), $\mathrm{Ba}$, and $\mathrm{Sr}$ and isotopic ratios of $\mathrm{Sr}, \mathrm{Nd}$, and $\mathrm{Ce}$ were determined for six samples of basalts drilled at Hole 504B on Leg 111 of the Ocean Drilling Program. Analyses found that these basalts are the most depleted in $\mathrm{Sr}, \mathrm{Ba}$, and light REE among mid-ocean ridge basalts (MORB); Ba depletion is especially notable. On the other hand, $\mathrm{Sr}, \mathrm{Nd}$, and $\mathrm{Ce}$ isotopic ratios for basalts from Hole 504B are within the range of typical MORB values.
\end{abstract}

\section{INTRODUCTION}

Studies of rare earth element (REE) abundances and Nd and $\mathrm{Sr}$ isotopic ratios of mid-ocean ridge basalts (MORB) contribute to our understanding of the formation of these rocks and the geochemical nature of the mantle from which MORB is derived. Recently, tracing of $\mathrm{Ce}$ isotopes based on the decay of ${ }^{138} \mathrm{La}$ to ${ }^{138} \mathrm{Ce}$ has been applied to studies of the petrogenesis and evolution of the Earth's crust and mantle (Tanaka and Masuda, 1982; Tanaka et al., 1987, 1988; Dickin, 1987a, 1987b, 1988; Dickin et al., 1987). Coupling analysis of the La-Ce system with the Sm-Nd system should be significant because both pairs belong to the rare earth group. In this chapter we report $\mathrm{REE}, \mathrm{Sr}$, and $\mathrm{Ba}$ abundances and isotopic ratios of $\mathrm{Sr}$ and $\mathrm{Nd}$ in Hole 504B basalts, recovered during Ocean Drilling Program (ODP) Leg 111 investigations of the Costa Rica Rift. The Ce isotopic ratio is reported for one sample.

Hole 504B, of Deep Sea Drilling Project (DSDP) Legs 69, 70 , and 83 and ODP Leg 111, is the deepest section of basement drilled in the ocean crust, in 5.9-Ma crust about $200 \mathrm{~km}$ south of the Costa Rica Rift. Hole 504B basalts are known to be the most depleted among MORB in incompatible elements such as $\mathrm{Th}, \mathrm{Ta}, \mathrm{Na}, \mathrm{Sr}$, and light REE; however, basalts moderately enriched in the incompatible elements-a different magma typewere also recovered (Autio and Rhodes, 1983; Marsh et al., 1983; Etoubleau et al., 1983; Kempton et al., 1985; Tual et al., 1985; Emmermann, 1985). Leg 111 deepened Hole 504B by $212.3 \mathrm{~m}$, to a total depth of $1562.3 \mathrm{~m}$ below seafloor (mbsf) or $1287.8 \mathrm{~m}$ into basement. New data for trace element abundances and isotopic ratios from this section of Hole 504B will help clarify the geochemical nature of the deepest recovery of MORB.

\section{METHODS}

Six samples from Hole 504B were analyzed; descriptions of Samples 111-504B-143R-1, 22-24 cm, 111-504B-145R-2, 62-64 cm, 111-504B148R-1, 83-88 cm, 111-504B-150R-1, 122-123 cm, 111-504B-163R-2, 29-31 cm, and 111-504B-169R-1, 102-105 cm, are in Table 1. The rocks recovered from Hole 504B during Leg 111 are aphyric or sparsely to highly phyric, fine- to medium-grained olivine tholeiitic basalts. Most are slightly altered.

After acid decomposition of the samples, REE, Ba, and Sr were separated from major elements by an $\mathrm{AG} 50 \mathrm{~W}-\mathrm{X} 8$ resin column in $\mathrm{HCl}$ me-

\footnotetext{
${ }^{1}$ Becker, K., Sakai, H., et al., 1989. Proc. ODP, Sci. Results, 111: College Station, TX (Ocean Drilling Program).

${ }^{2}$ Laboratory for REE Microanalysis, Department of Chemistry, Faculty of Science, The University of Tokyo, Hongo, Tokyo 113, Japan.
}

Table 1. Descriptions of samples analyzed, Hole 504B, Leg 111 (Shipboard Scientific Party, 1988).

\begin{tabular}{cc}
\hline $\begin{array}{c}\text { Core, section, } \\
\text { interval }(\mathrm{cm})\end{array}$ & \multicolumn{1}{c}{ Description } \\
\hline $143 \mathrm{R}-1,22-24$ & $\begin{array}{c}\text { Moderately plagioclase-olivine-clinopyroxene } \\
\text { phyric basalt }\end{array}$ \\
$145 \mathrm{R}-2,62-64$ & $\begin{array}{c}\text { Moderately clinopyroxene-plagioclase-olivine } \\
\text { phyric basalt }\end{array}$ \\
$148 \mathrm{R}-1,83-88$ & $\begin{array}{c}\text { Moderately plagioclase-clinopyroxene-olivine } \\
\text { phyric basalt }\end{array}$ \\
$150 \mathrm{R}-1,122-123$ & $\begin{array}{c}\text { Sparsely olivine-clinopyroxene-plagioclase } \\
\text { phyric basalt }\end{array}$ \\
$163 \mathrm{R}-2,29-31$ & $\begin{array}{c}\text { Moderately plagioclase-olivine-clinopyroxene } \\
\text { phyric basalt }\end{array}$ \\
$169 \mathrm{R}-1,102-105$ & $\begin{array}{c}\text { Moderately clinopyroxene-olivine-plagioclase } \\
\text { phyric basalt }\end{array}$ \\
\hline
\end{tabular}

dia. Ce and $\mathrm{Nd}$ for isotopic analysis were separated using an AG5OW$\mathrm{X} 8$ resin column with $\alpha$-hydroxy-isobutyric acid. REE, Sr, and $\mathrm{Ba}$ abundances were determined on a JEOL JMS-05RB mass spectrometer by the isotope dilution method. Isotopic compositions of $\mathrm{Sr}$ and $\mathrm{Nd}$ were measured on a VG 354 mass spectrometer using three and five Faraday collectors, respectively. Ce isotopic composition was measured on a VG 54-38 double-focusing mass spectrometer. The measured isotopic ratios of $\mathrm{Sr}, \mathrm{Nd}$, and Ce were normalized against ${ }^{86} \mathrm{Sr} /{ }^{88} \mathrm{Sr}=0.1194,{ }^{146} \mathrm{Nd} /$ ${ }^{144} \mathrm{Nd}=0.7219$, and ${ }^{136} \mathrm{Ce} /{ }^{142} \mathrm{Ce}=0.01688$, respectively. Details of our Ce isotope measurement are described elsewhere (Makishima et al., 1987).

Isotopic ratios were measured for the standard salts as follows: ${ }^{87} \mathrm{Sr} /$ ${ }^{86} \mathrm{Sr}$ ratio for NBS987 $\mathrm{Sr}$ standard was $0.71019 \pm 4\left(2 \sigma_{\mathrm{m}}\right) ;{ }^{143} \mathrm{Nd} /{ }^{144} \mathrm{Nd}$ ratios for La Jolla $\mathrm{Nd}$ standard and for Johnson Matthey $\mathrm{Nd}_{2} \mathrm{O}_{3}$ (JMC32l, batch no. S.810931A) were $0.511823 \pm 16$ and $0.511080 \pm$ 12 , respectively; and ${ }^{138} \mathrm{Ce} /{ }^{142} \mathrm{Ce}$ ratio for Johnson Matthey $\mathrm{CeO}_{2}$ (JMC304) was $0.0225775 \pm 14$. Our ${ }^{143} \mathrm{Nd} /{ }^{144} \mathrm{Nd}$ ratios for both $\mathrm{La}$ Jolla standard and Johnson Matthey $\mathrm{Nd}_{2} \mathrm{O}_{3}$ exhibit slightly lower values than those reported by O'Nions et al. (1977), Jahn et al. (1980), Lugmair et al. (1983), and Bell and Blenkinsop (1987) (Table 2).

In plotting chondrite-normalized $\mathrm{REE}, \mathrm{Sr}$, and $\mathrm{Ba}$ abundances, a linear scale as well as a logarithmic scale was used for the ordinate axis, following Shimizu et al.'s (1980) strategy for distinguishing REE patterns of abyssal tholeiites. Masuda (1979) explained the advantage and theoretical significance of linear scale plotting for solid-type igneous rocks or potentially for the conjugate relationship between the solidand liquid-type rocks, based on the model originally presented by Masuda and Matsui (1966) and further developed by Masuda. In Masuda's (1979) model, the basic evolutionary framework for the REE patterns of whole-rock samples of common igneous rocks is determined by the solidification process, starting from melt with a chondritic REE abundance ratio as a linear bulk-partition coefficient function. Thus, for incipient solid-phase REE patterns, using a linear scale for the vertical axis is advantageous in demonstrating rectilinearity, whereas a logarithmic scale is significant for plotting liquid-type material systems. 
Table 2. Comparison of ${ }^{143} \mathrm{Nd} /{ }^{144} \mathrm{Nd}$ ratios for Nd standard salts.

\begin{tabular}{lcc}
\hline & La Jolla standard & JMC 321 $\mathrm{Nd}_{2} \mathrm{O}_{3}$ \\
\hline This study & $0.511823 \pm 0.000016$ & $0.511080 \pm 0.000012$ \\
Lugmair et al. (1983) & $0.511858 \pm 0.000004$ & - \\
Bell and Blenkinsop (1987) & $0.51186 \pm 0.00002$ & - \\
O'Nions et al. (1977) & - & $0.51112 \pm 0.00003$ \\
Jahn et al. (1980) & - & $0.511137 \pm 0.000008$ \\
\hline
\end{tabular}

Note: Errors are $2 \sigma_{\mathrm{m}}$. The ${ }^{143} \mathrm{Nd} /{ }^{144} \mathrm{Nd}$ ratio by Lugmair et al. (1983) was normalized against ${ }^{148} \mathrm{Nd} /{ }^{144} \mathrm{Nd}=0.241572$, and the ${ }^{146} \mathrm{Nd} /{ }^{144} \mathrm{Nd}$ correspondingly obtained was $0.721878 \pm 0.000007$ for the La Jolla Nd standard. The Nd isotopic ratios from O'Nions et al. (1977), Jahn et al. (1980), Bell and Blenkinsop (1987), and this study were normalized against ${ }^{146} \mathrm{Nd} /$ ${ }^{144} \mathrm{Nd}=0.7219$

\section{RESULTS AND DISCUSSION}

\section{REE, Ba, and $\mathrm{Sr}$ Abundances}

$\mathrm{REE}, \mathrm{Sr}$, and $\mathrm{Ba}$ abundances for four samples are listed in Table 3 and presented on chondrite-normalized patterns (Masuda-Coryell plot; Masuda, 1962; Coryell et al., 1963) in Figure 1. The depletion of $\mathrm{Ba}(0.70-0.89 \mathrm{ppm})$ is remarkable. Ba abundance in oceanic tholeiitic basalts ranges from several to several hundred parts per million and averages 14.5 ppm in Puchelt's (1972) list of Ba concentration in terrestrial rocks. Similar typical Ba abundances of $12.2 \mathrm{ppm}$ for Type I MORB and $55 \mathrm{ppm}$ for Type II MORB are reported by the Basaltic Volcanism Study Project (1981). In comparison to Bryan et al.'s (1976) classification, Type I corresponds to basalt erupted along the "normal" topographic section of mid-ocean ridges and Type II corresponds to basalt produced at elevated sections of mid-ocean ridges adjacent to volcanic platforms associated with oceanic islands. Sr abundances in the Hole 504B basalts are also low (54$61 \mathrm{ppm})$, but are not as depleted as $\mathrm{Ba}$ abundances. Faure (1986) reported $\mathrm{Sr}$ abundances ranging from 96 to $154 \mathrm{ppm}$ for oceanic tholeiites from the Pacific Ocean. The average $\mathrm{Sr}$ concentrations summarized by the Basaltic Volcanism Study Project (1981) are 127 and 105 ppm for Type I and Type II MORB, respectively.

$(\mathrm{La} / \mathrm{Sm})_{\mathrm{N}}$ values around 0.3 for Hole 504B samples (Table 3) are lower than the 0.4-0.7 values of MORB from the corresponding normal ridge segment (Sun et al., 1979), suggesting

Table 3. REE, Ba, and $\mathrm{Sr}$ abundances (ppm) in Hole 504B basalts.

\begin{tabular}{lccccc}
\hline \multicolumn{5}{c}{ Sample } & \\
\cline { 2 - 4 } Element & $\begin{array}{c}143 \mathrm{R}-1, \\
22-24 \mathrm{~cm}\end{array}$ & $\begin{array}{c}145 \mathrm{R}-2, \\
62-64 \mathrm{~cm}\end{array}$ & $\begin{array}{c}148 \mathrm{R}-1, \\
83-88 \mathrm{~cm}\end{array}$ & $\begin{array}{c}163 \mathrm{R}-2 \\
29-31 \mathrm{~cm}\end{array}$ & $\begin{array}{c}\text { Normalizing } \\
\text { value }^{\mathrm{a}}\end{array}$ \\
\hline $\mathrm{La}$ & 1.177 & 1.023 & 1.23 & 1.086 & 0.378 \\
$\mathrm{Ce}$ & 4.59 & 3.98 & 4.97 & 4.44 & 0.976 \\
$\mathrm{Nd}$ & 5.44 & 4.71 & 5.98 & 5.36 & 0.716 \\
$\mathrm{Sm}$ & 2.27 & 1.95 & 2.39 & 2.25 & 0.230 \\
$\mathrm{Eu}$ & 0.842 & 0.727 & 0.921 & 0.809 & 0.0866 \\
$\mathrm{Gd}$ & 3.51 & 2.95 & 3.73 & 3.35 & 0.311 \\
$\mathrm{Dy}$ & 4.51 & 3.79 & 4.74 & 4.36 & 0.390 \\
$\mathrm{Er}$ & 2.91 & 2.44 & 3.08 & 2.74 & 0.255 \\
$\mathrm{Yb}$ & 2.86 & 2.31 & 3.01 & 2.65 & 0.249 \\
$\mathrm{Lu}$ & 0.431 & 0.338 & 0.453 & 0.359 & 0.0387 \\
$\mathrm{Ba}$ & 0.887 & 0.695 & 0.768 & 0.705 & 4.21 \\
$\mathrm{Sr}$ & 56.5 & 54.4 & 59.7 & 61.3 & 11.1 \\
$\mathrm{Ratios}$ between & chrondrite-normalized values & & \\
$(\mathrm{La} / \mathrm{Sm})_{\mathrm{N}}$ & 0.316 & 0.319 & 0.313 & 0.294 & - \\
$(\mathrm{Ce} / \mathrm{Yb})_{\mathrm{N}}$ & 0.409 & 0.440 & 0.421 & 0.428 & - \\
\end{tabular}

${ }^{\mathrm{a}}$ Normalizing values for REE and $\mathrm{Ba}$ are from abundances of these elements in Leedey chondrite (Masuda et al., 1973; Nakamura and Masuda, 1973). The normalizing value for $\mathrm{Sr}, 11.1 \mathrm{ppm}$, is from Gopalan and Wetherill (1971). strong depletion of light REE in the Hole 504B basalts. Sr and $\mathrm{Ba}$ abundances increase with increasing $(\mathrm{La} / \mathrm{Sm})_{\mathrm{N}}$ values and the Hole 504B basalts fall in the lowest value ranges (Figs. 2 and 3).

The chondrite-normalized REE patterns of four samples from Hole 504B are similar to each other, with some variation of fine structures in heavy REE span (Fig. 4). Generally, La, Ce, and $\mathrm{Nd}$ plot along a straight line, but $\mathrm{Ce}$ has a positive deviation from a La-Ce-Nd regression line whereas $\mathrm{La}$ and $\mathrm{Nd}$ deviate in a negative direction. (From a theoretical viewpoint, these deviations indicate an expected slight curvature.) REE patterns of basalts from Holes 417A and 417D (DSDP Leg 51, the Bermuda Rise; Shimizu et al., 1980) have the same features as observed for the Hole 504B La-Ce-Nd span. In plots of Samples 111-504B-143R-1, 22-24 cm, and 111-504B-148R-1, 83-88 cm, $\mathrm{Gd}$, Dy, Er, and $\mathrm{Yb}$ appear to fall along a straight horizontal line, whereas heavy REE for Samples 111-504B-145R-2, 62-64 $\mathrm{cm}$, and 111-504B-163R-2, 29-31 cm, show slightly curved features with a maximum at Dy.

\section{$\mathrm{Sr}$, Nd, and Ce Isotopic Ratios}

The isotopic ratios of $\mathrm{Sr}, \mathrm{Nd}$, and Ce listed in Table 4 are essentially unaffected by alteration. ${ }^{87} \mathrm{Sr} /{ }^{86} \mathrm{Sr}$ ratios for five samples from this study are between 0.7024 and 0.7028 , with a mean of 0.70266 . A similar value of 0.70266 was reported as a mean ${ }^{87} \mathrm{Sr} /{ }^{86} \mathrm{Sr}$ ratio for the Hole $504 \mathrm{~B}$ basalts recovered from 330 to $560 \mathrm{~m}$ within basement during Legs 69 and 70 (Barret and Friedrichsen, 1982; Barret, 1983), which is almost identical to the average isotopic value of fresh MORB. On the other hand, Barret and Friedrichsen (1982) and Barret (1983) found higher ${ }^{87} \mathrm{Sr} /{ }^{86} \mathrm{Sr}$ ratios, with a mean of 0.70320 , in samples from the upper $260-\mathrm{m}$ interval within basement at Hole 504B, and they interpreted these higher ratios in terms of strontium-isotope alteration during basalt-seawater interaction. Furthermore, for the Hole 504B basalts in the 580-1075-m interval within basement (Leg 83), higher and scattered ${ }^{87} \mathrm{Sr} /{ }^{86} \mathrm{Sr}$ ratios between 0.7025 and 0.7068 and with a mean of 0.7038 were reported by Friedrichsen (1985). Based on strontium, oxygen, and hydrogen isotopic compositions, Friedrichsen (1985) suggested the existence of a seawater/crust interface, now at a depth of $620 \mathrm{~m}$ within basement, during high-temperature water-rock interactions. The ${ }^{87} \mathrm{Sr} /{ }^{86} \mathrm{Sr}$ ratios obtained from our investigation have an average value similar to that for fresh MORB, suggesting that basalts in the $1075-1287-\mathrm{m}$ interval within basement have undergone little alteration.

The ${ }^{143} \mathrm{Nd} /{ }^{144} \mathrm{Nd}$ and ${ }^{87} \mathrm{Sr} /{ }^{86} \mathrm{Sr}$ ratios of the Hole 504B basalts are similar to those reported for oceanic basalts from the Pacific, including the East Pacific Rise and Juan de Fuca and Galapagos ridges (Fig. 5) (Cohen et al., 1980; White and Hofmann, 1982). The similarity of the ${ }^{143} \mathrm{Nd} /{ }^{144} \mathrm{Nd}$ and ${ }^{138} \mathrm{Ce} /$ ${ }^{142} \mathrm{Ce}$ ratios of Sample 111-504B-143R-1, 22-24 cm, to MORB ratios from the Mid-Atlantic Ridge $\left(22^{\circ} 59.14^{\prime} \mathrm{N}, 43^{\circ} 30.39^{\prime} \mathrm{W}\right.$, and $\left.23^{\circ} 02.63^{\prime} \mathrm{N}, 45^{\circ} 01.05^{\prime} \mathrm{W}\right)$ and East Pacific Rise $\left(12^{\circ} 52^{\prime} \mathrm{S}\right.$, $11^{\circ} 57^{\prime} \mathrm{W}$ ) (Tanaka et al., 1987) is evident in Figure 6.

Although a limited number of isotopic ratios were determined in this study, the $\mathrm{Sr}, \mathrm{Nd}$, and $\mathrm{Ce}$ isotopic ratios for Hole 504B basalts are within the range of typical MORB values. With respect to the trace element abundances, however, high depletion of incompatible elements in the Hole 504B basalts is not typical of MORB.

\section{Isotopic Evolution of $\mathrm{Nd}$}

The isotopic evolution of $\mathrm{Nd}$ from Hole 504B basalts and depleted mantle relative to chondritic uniform reservoir (CHUR) is shown in Figure 7. Present-day CHUR values are ${ }^{143} \mathrm{Nd} /{ }^{144} \mathrm{Nd}$ $=0.512638$ and ${ }^{147} \mathrm{Sm} /{ }^{144} \mathrm{Nd}=0.1966$ (Wasserburg et al., 1981). Two sets of corresponding values for present-day de- 


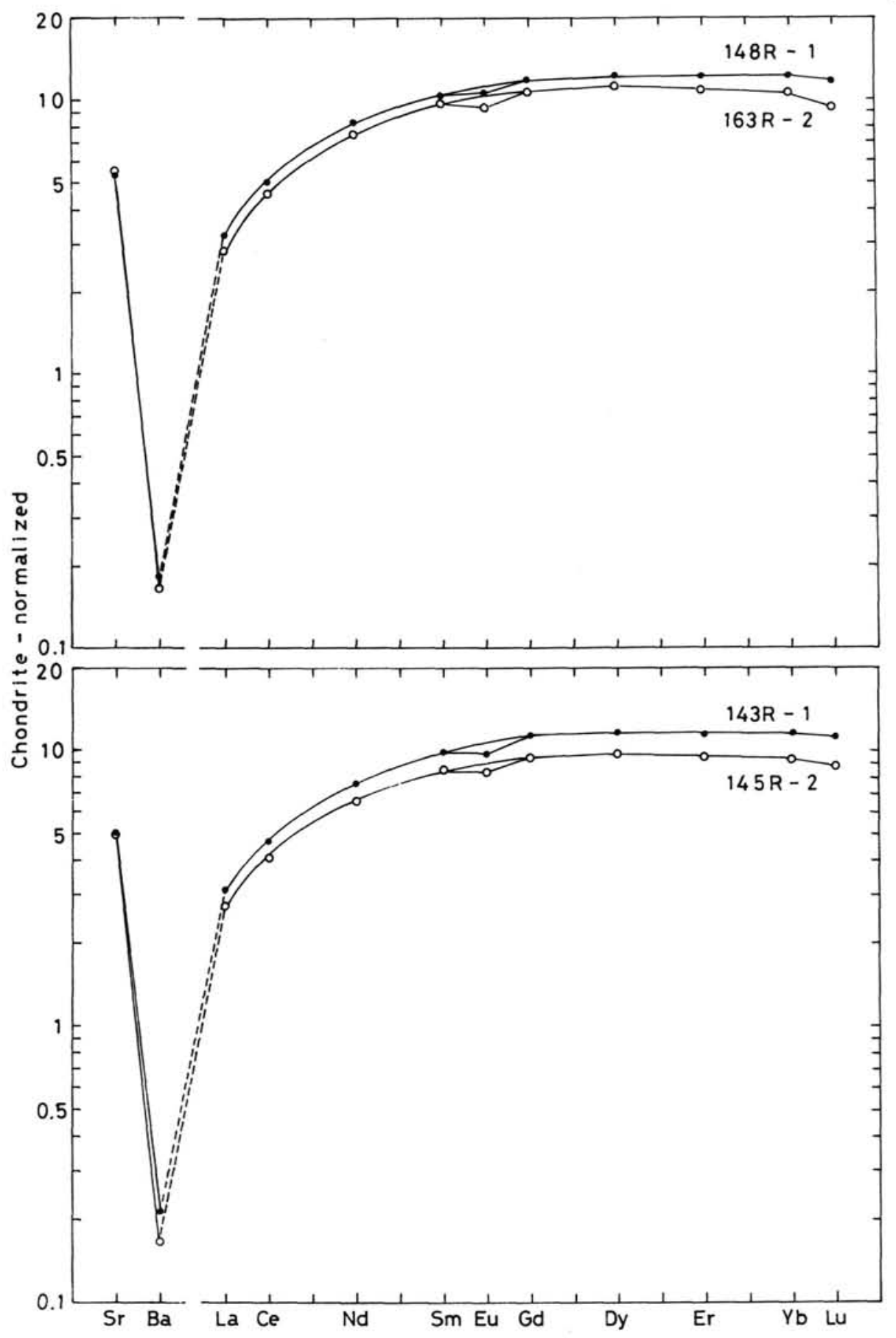

Figure 1. Chondrite-normalized (logarithmic scale) REE-Ba-Sr patterns of Hole 504B basalts (Samples 111-504B-143R-1, 22-24 cm, 111-504B-145R-2, 62-64 cm, 111-504B-148R-1, 83-88 cm, and 111-504B-163R-2, 29-31 cm). Normalizing values for REE and $\mathrm{Ba}$ are from abundances of these elements in Leedey chondrite (Masuda et al., 1973; Nakamura and Masuda, 1973). The normalizing value for Sr, $11.1 \mathrm{ppm}$, is from Gopalan and Wetherill (1971).

pleted mantle were chosen for average MORB; the first set of parameters for depleted mantle (DM-A) is ${ }^{143} \mathrm{Nd} /{ }^{144} \mathrm{Nd}=0.5131$ $\left(\epsilon_{\mathrm{Nd}}=+9.0\right)$ and ${ }^{147} \mathrm{Sm} /{ }^{144} \mathrm{Nd}=0.2238$ (Hawkesworth and van Calsteren, 1984) and the second set (DM-B) is ${ }^{143} \mathrm{Nd} /{ }^{144} \mathrm{Nd}$ $=0.513153\left(\epsilon_{\mathrm{Nd}}=+10.0\right)$ and ${ }^{147} \mathrm{Sm} /{ }^{144} \mathrm{Nd}=0.225($ Liew and McCulloch, 1985).

One of the simplest interpretations of the $\mathrm{Nd}$ isotopic ratios of the Hole 504B basalts is that the basalts were generated from CHUR with the same $\mathrm{Sm} / \mathrm{Nd}$ ratios as the samples at ages in the CHUR model of $1.4 \times 10^{9}$ to $1.7 \times 10^{9} \mathrm{yr}$ (Table 5 and Fig. 7). Another, more likely interpretation is that these basalts were derived from depleted mantle sources with a $\mathrm{Sm} / \mathrm{Nd}$ ratio close to average MORB and subsequently experienced further depletion in incompatible elements. Redepletion occurred between 200 and $600 \mathrm{Ma}$ for DM-A, with ${ }^{143} \mathrm{Nd} /{ }^{144} \mathrm{Nd}=0.5131\left(\epsilon_{\mathrm{Nd}}=\right.$ +9.0 ) and ${ }^{147} \mathrm{Sm} /{ }^{144} \mathrm{Nd}=0.2238$ (Hawkesworth and van Calsteren, 1984), whereas redepletion is younger than $365 \mathrm{Ma}$ for $\mathrm{DM}-\mathrm{B}$, with ${ }^{143} \mathrm{Nd} /{ }^{144} \mathrm{Nd}=0.513153\left(\epsilon_{\mathrm{Nd}}=+10.0\right)$ and 


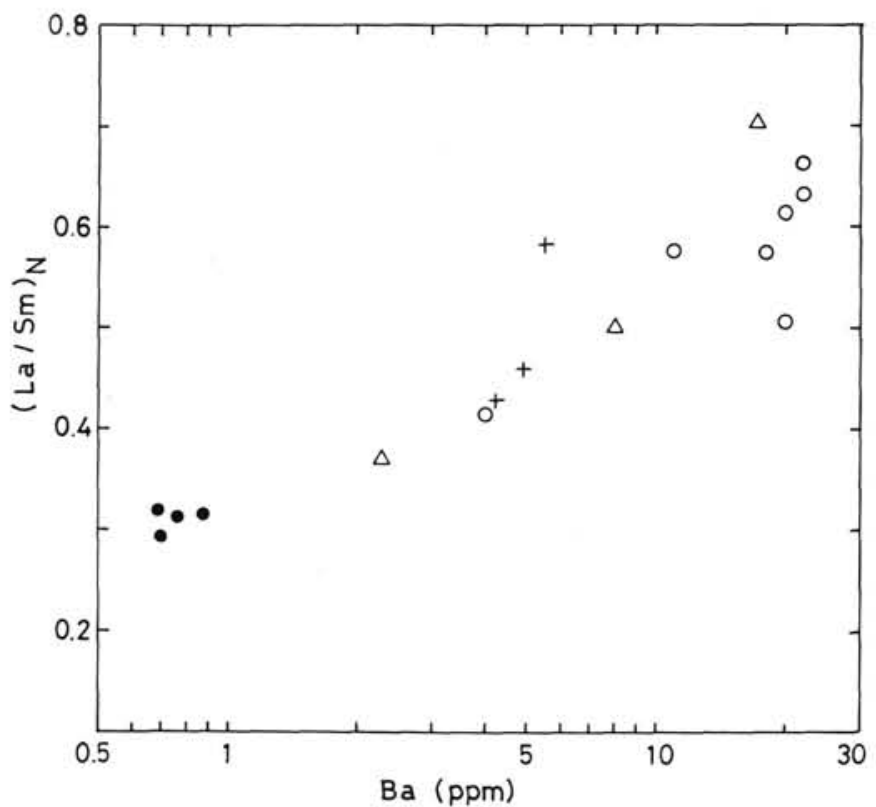

Figure 2. $(\mathrm{La} / \mathrm{Sm})_{\mathrm{N}}$ vs. Ba concentration for MORB. Open circles $=$ Legs 2 and 3, Atlantic Ocean floor (Frey et al., 1974); triangles = MidAtlantic and Mid-Indian ridges (Sun et al., 1979); crosses = Holes 417A and 417D and Mid-Atlantic Ridge (Shimizu et al., 1980); solid circles $=$ Hole 504B (this study).

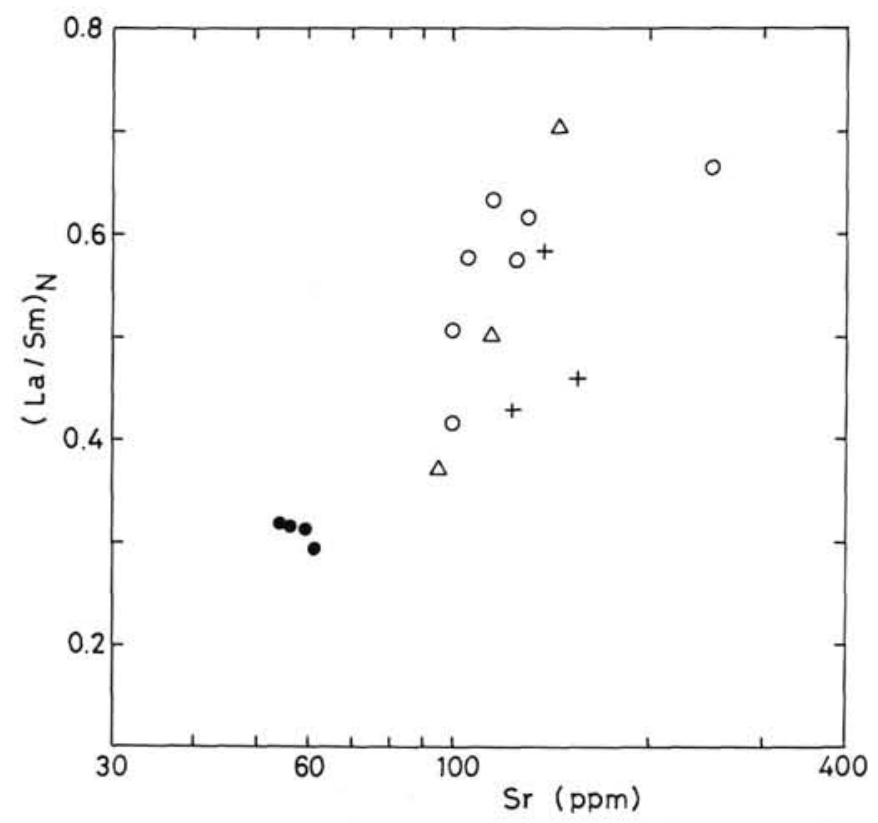

Figure 3. $(\mathrm{La} / \mathrm{Sm})_{\mathrm{N}}$ vs. Sr concentration for MORB. Symbols same as for Figure 2.

${ }^{147} \mathrm{Sm} /{ }^{144} \mathrm{Nd}=0.225$ (Liew and McCulloch, 1985). In the latter case, the redepletion process may be related to a formation series of basalts. A probable mechanism would be a limited partial-melting event just prior to basalt formation (i.e., a precursory partial melting). For either scenario, the sources of the Hole 504B basalts were probably derived from depleted mantle and underwent further depletion in incompatible elements. This model would satisfactorily explain the isotopic and abundance data for the Hole 504B basalts of $\mathrm{Sr}, \mathrm{Nd}$, and $\mathrm{Ce}$ isotopic ratios with typical values of MORB but with further depletion of incompatible elements.

\section{CONCLUSIONS}

The basalts from Hole 504B are the most depleted in $\mathrm{Sr}, \mathrm{Ba}$, and light REE among MORB. Strong depletion of REE is suggested by $(\mathrm{La} / \mathrm{Sm})_{\mathrm{N}}$ ratios around 0.3 in the Hole 504B basalts, which are lower than the corresponding values of 0.4-0.7 for MORB from normal ridge segments. $\mathrm{Ba}$ abundances are extremely low $(0.7-0.9 \mathrm{ppm})$, but the isotopic ratios of $\mathrm{Sr}, \mathrm{Nd}$, and $\mathrm{Ce}$ for Hole 504B basalts are within the range of typical MORB ratios. These data are explained by a model of basalt formation from sources depleted in incompatible elements, such as average MORB, that underwent further depletion caused by a precursory episode of limited partial melting.

\section{ACKNOWLEDGMENTS}

We thank Dr. T. Tanaka, Geological Survey of Japan, for Ce and Nd isotopic standard solutions and Dr. S. Nakai, the University of Tokyo, for his help in the experiments. This research was supported by a grantin-aid for scientific research from the Ministry of Education, Science and Culture of Japan.

\section{REFERENCES}

Autio, L. K., and Rhodes, J. M., 1983. Costa Rica Rift zone basalts: geochemical and experimental data from a possible example of multistage melting. In Cann, J. R., Langseth, M. G., Honnorez, J., Von Herzen, R. P., White, S. M., et al., Init. Repts. DSDP, 69: Washington (U.S. Govt. Printing Office), 729-745.

Barrett, T. J., 1983. Strontium- and lead-isotope composition of some basalts from Deep Sea Drilling Project Hole 504B, Costa Rica Rift, Legs 69 and 70. In Cann, J. R., Langseth, M. G., Honnorez, J., Von Herzen, R. P., White, S. M., et al., Init. Repts. DSDP, 69: Washington (U.S. Govt. Printing Office), 643-650.

Barrett, T. J., and Friedrichsen, H., 1982. Strontium and oxygen isotopic composition of some basalts from Hole 504B, Costa Rica Rift, DSDP Legs 69 and 70. Earth Planet. Sci. Lett., 60:27-38.

Basaltic Volcanism Study Project, 1981. Ocean-floor basaltic volcanism. In Basaltic Volcanism on the Terrestrial Planets: New York (Pergamon), 132-160.

Bell, K., and Blenkinsop, J., 1987. Archean depleted mantle: evidence from $\mathrm{Nd}$ and $\mathrm{Sr}$ initial isotopic ratios of carbonatites. Geochim. Cosmochim. Acta, 51:291-298.

Bryan, W. B., Thompson, G., Frey, F. A., and Dickey, J. S., 1976. Inferred settings and differentiation in basalts from the Deep Sea Drilling Project. J. Geophys. Res., 81:4285-4304.

Cohen, R. S., Evensen, N. M., Hamilton, P. J., and O'Nions, R. K., 1980. U-Pb, Sm-Nd and Rb-Sr systematics of mid-ocean ridge basalt glasses. Nature, 283:149-153.

Coryell, C. D., Chase, J. W., and Winchester, J. W., 1963. A procedure for geochemical interpretation of terrestrial rare-earth abundance patterns. J. Geophys. Res., 68:559-566.

Dickin, A. P., 1987a. Cerium isotope geochemistry of ocean island basalts. Nature, 326:283-284. 1987b. La-Ce dating of Lewisian granulites to constrain the ${ }^{138}$ La $\beta$-decay half-life. Nature, 325:337-338. 333:403.

Dickin, A. P., Jones, N. W., Thirwall, M. F., and Thompson, R. N., 1987. A Ce/Nd isotope study of crustal contamination processes af fecting Palaeocene magmas in Skye, northwest Scotland. Contrib. Mineral. Petrol., 96:455-464.

Emmerman, R., 1985. Basement geochemistry, Hole 504B. In Anderson, R. N., Honnorez, J., Becker, K., et al., Init. Repts. DSDP, 83: Washington (U.S. Govt. Printing Office), 129-164.

Etoubleau, J., Corre, O., Joron, J. L., Bougault, H., and Treuil, M., 1983. Costa Rica Rift: variably depleted basalts in the same hole. In Cann, J. R., Langseth, M. G., Honnorez, J., Von Herzen, R. P., White, S. M., et al., Init. Repts. DSDP, 69: Washington (U.S. Govt. Printing Office), 765-773.

Faure, G., 1986. Principles of Isotope Geology: New York (Wiley). 
Frey, F. A., Bryan, W. B., and Thompson, G., 1974. Atlantic Ocean floor: geochemistry and petrology of basalts from Legs 2 and 3 of the Deep Sea Drilling Project. J. Geophys. Res., 79:5507-5527.

Friedrichsen, H., 1985. Strontium, oxygen, and hydrogen isotope studies on primary and secondary minerals in basalts from the Costa Rica Rift, Deep Sea Drilling Project Hole 504B, Leg 83. In Anderson, R. N., Honnorez, J., Becker, K., et al., Init. Repts. DSDP, 83: Washington (U.S. Govt. Printing Office), 289-295.

Gopalan, K., and Wetherill, G. W., 1971. Strontium. In Mason, B. (Ed.), Handbook of Elemental Abundances in Meteorites: New York (Gordon and Breach), 297-302.

Hawkesworth, C. J., and van Calsteren, P.W.C., 1984. Radiogenic isotopes: some geological applications. In Henderson, P. (Ed.), Rare Earth Element Geochemistry: Amsterdam (Elsevier), 375-421.

Jahn, B. M., Griffiths, J. B., Charlot, R., Cornichet, J., and Vidal, F., 1980. Nd and $\mathrm{Sr}$ isotopic compositions and REE abundances of Cretaceous MORB (Holes 417D and 418A, Legs 51, 52 and 53). Earth Planet. Sci. Lett., 48:171-184.

Kempton, P. D., Autio, L. K., Rhodes, J. M., Holdaway, M. J., Dungan, M. A., and Johnson, P., 1985. Petrology of basalts from Hole 504B, Deep Sea Drilling Project, Leg 83. In Anderson, R. N., Honnorez, J., Becker, K., et al., Init. Repts. DSDP, 83: Washington (U.S. Govt. Printing Office), 129-164.

Liew, T. C., and McCulloch, M. T., 1985. Genesis of granitoid batholiths of peninsular Malaysia and implications for models of crustal evolution: evidence from a $\mathrm{Nd}-\mathrm{Sr}$ isotopic and U-Pb zircon study. Geochim. Cosmochim. Acta, 49:587-600.

Lugmair, G. W., Shimamura, T., Lewis, R. S., and Anders, E., 1983. Samarium-146 in the early solar system: evidence from neodymium in the Allende meteorite. Science, 222:1015-1018.

Makishima, A., Shimizu, H., and Masuda, A., 1987. Precise measurement of cerium and lanthanum isotope ratios. Mass Spectrosc., 35: 64-72.

Marsh, N. G., Tarney, J., and Hendry, G. L., 1983. Trace element geochemistry of basalts from Hole 504B, Panama Basin, Deep Sea Drilling Project Legs 69 and 70. In Cann, J. R., Langseth, M. G., Honnorez, J., Von Herzen, R. P., White, S. M., et al., Init. Repts. DSDP, 69: Washington (U.S. Govt. Printing Office), 747-763.

Masuda, A., 1962. Regularities in variation of relative abundances of lanthanide elements and an attempt to analyse separation index patterns of some minerals. J. Earth Sci. Nagoya Univ., 10:173-187. 1979. Effects of linear bulk partition coefficient functions of REE: liquid-type and solid-type patterns as a basic framework. $J$. Earth Sci. Nagoya Univ., 26/27:75-92.

Masuda, A., and Matsui, Y., 1966. The difference in lanthanide abundance pattern between the crust and the chondrite and its possible meaning to the genesis of crust and mantle. Geochim. Cosmochim. Acta, 30:239-250.

Masuda, A., Nakamura, N., and Tanaka, T., 1973. Fine structures of mutually normalized rare-earth patterns of chondrites. Geochim. Cosmochim. Acta, 37:239-248.
Nakamura, N., and Masuda, A., 1973. Chondrites with peculiar rareearth patterns. Earth Planet. Sci. Lett., 19:429-437.

O’Nions, R. K., Hamilton, P. J., and Evensen, N. M., 1977. Variations in ${ }^{143} \mathrm{Nd} /{ }^{144} \mathrm{Nd}$ and ${ }^{87} \mathrm{Sr} /{ }^{86} \mathrm{Sr}$ ratios in oceanic basalts. Earth Planet. Sci. Lett., 34:13-22.

Puchelt, H., 1972. Barium. In Wedepohl, K. H. (Ed.), Handbook of Geochemistry: Berlin (Springer-Verlag).

Shimizu, H., Masuda, A., and Ui, T., 1980. Determination of rareearth elements in Leg 51, Site 417 samples. In Donnelly, T., Francheteau, J., Bryan, W., Robinson, P., Flower, M., Salisbury, M., et al., Init. Repts. DSDP, 51, 52, 53, Pt. 2: Washington (U.S. Govt. Printing Office), 1113-1120.

Shimizu, H., Nakai, S., Tasaki, S., Masuda, A., Bridgwater, D., Nutman, A. P., and Baadsgaard, H., 1988. Geochemistry of Ce and Nd isotopes and REE abundances in the Amitsoq gneisses, West Greenland. Earth Planet Sci. Lett., 91:159-169.

Shimizu, H., Tanaka, T., and Masuda, A., 1984. Meteoritic ${ }^{138} \mathrm{Ce} /{ }^{142} \mathrm{Ce}$ ratio and its evolution. Nature, 307:251-252.

Shipboard Scientific Party, 1988. Site 504. In Becker, K., Sakai, H., et al., Proc. ODP, Init. Repts., 111: College Station, TX (Ocean Drilling Program), 35-251.

Sun, S. S., Nesbitt, R. W., and Sharaskin, A. Y., 1979. Geochemical characteristics of mid-ocean ridge basalts. Earth Planet. Sci. Lett., 44:119-138.

Tanaka, T., and Masuda, A., 1982. The La-Ce geochronometer: a new dating method. Nature, 300:515-518.

Tanaka, T., Shimizu, H., Kawata, Y., and Masuda, A., 1987. Combined $\mathrm{La}-\mathrm{Ce}$ and $\mathrm{Sm}-\mathrm{Nd}$ isotope systematics in petrogenetic studies. $\mathrm{Na}$ ture, 327:113-117. 333:404

Tual, E., Jahn, B. M., Bougault, H., and Joron, J. L., 1985. Geochemistry of basalts from Hole 504B, Leg 83, Costa Rica Rift. In Anderson, R. N., Honnorez, J., Becker, K., et al., Init. Repts. DSDP, 83: Washington (U.S. Govt. Printing Office), 201-214.

Wasserburg, G. J., Jacobsen, S. B., DePaolo, D. J., McCulloch, M. T., and Wen, T., 1981. Precise determination of $\mathrm{Sm} / \mathrm{Nd}$ ratios, $\mathrm{Sm}$ and Nd isotopic abundances in standard solutions. Geochim. Cosmochim. Acta, 45:2311-2323.

White, W. M., and Hofmann, A. W., 1982. Sr and Nd isotope geochemistry of ocean basalts and mantle evolution. Nature, 296:821825 .

\section{Ms 111B-123}

Date of initial receipt: 25 April 1988

Date of acceptance: 8 August 1988

Table 4. Sr, Nd, and Ce isotopic compositions in Hole 504B basalts.

\begin{tabular}{|c|c|c|c|c|}
\hline $\begin{array}{l}\text { Core, section, } \\
\text { interval }(\mathrm{cm})\end{array}$ & ${ }^{87} \mathrm{Sr} /{ }^{86} \mathrm{Sr}$ & ${ }^{143} \mathrm{Nd} /{ }^{144} \mathrm{Nd}$ & $\left(\epsilon_{N}\right)^{a}$ & ${ }^{138} \mathrm{Ce} /{ }^{142} \mathrm{Ce}^{\mathrm{b}}$ \\
\hline $143 \mathrm{R}-1,22-24$ & - & $0.513141 \pm 0.000006$ & $(+9.8)$ & $0.0225689 \pm 0.0000036$ \\
\hline $145 \mathrm{R}-2,62-64$ & $0.70247 \pm 0.00001$ & $0.513102 \pm 0.000007$ & $(+9.1)$ & - \\
\hline $148 \mathrm{R}-1,83-88$ & $0.70271 \pm 0.00004$ & $0.513115+0.000006$ & $(+9.3)$ & - \\
\hline $150 \mathrm{R}-1,122-123$ & $0.70257 \pm 0.00002$ & - & $(-)$ & - \\
\hline $163 R-2,29-31$ & $0.70283 \pm 0.00006$ & $0.513187 \pm 0.000005$ & $(+10.7)$ & - \\
\hline $169 \mathrm{R}-1,102-105$ & $0.70272 \pm 0.00001$ & - & $(-)$ & - \\
\hline
\end{tabular}




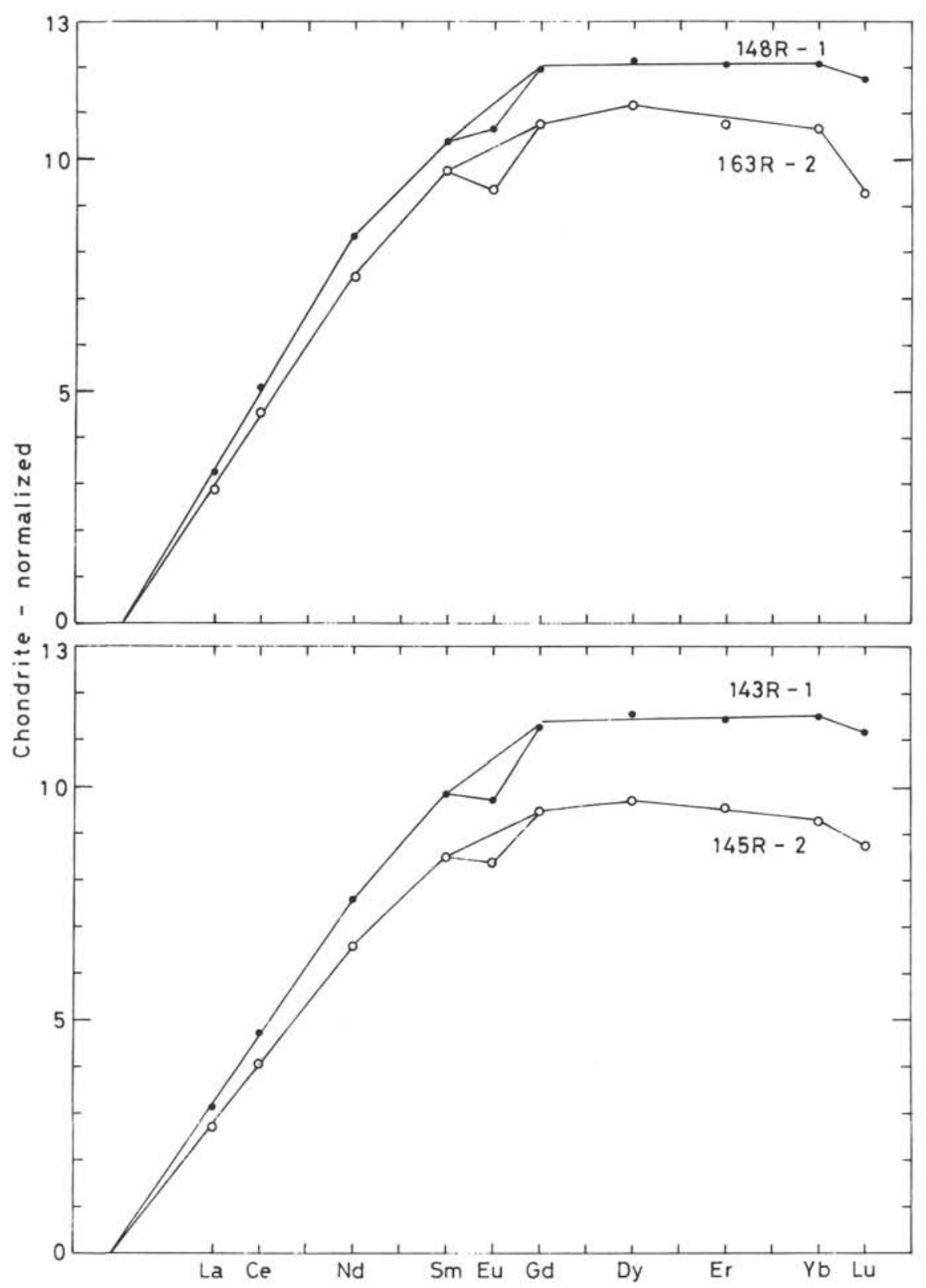

Figure 4. Chondrite-normalized (linear scale) REE patterns of Hole 504B basalts (Samples 111504B-143R-1, 22-24 cm, 111-504B-145R-2, 62-64 cm, 111-504B-148R-1, 83-88 cm, and 111504B-163R-2, 29-31 cm). 


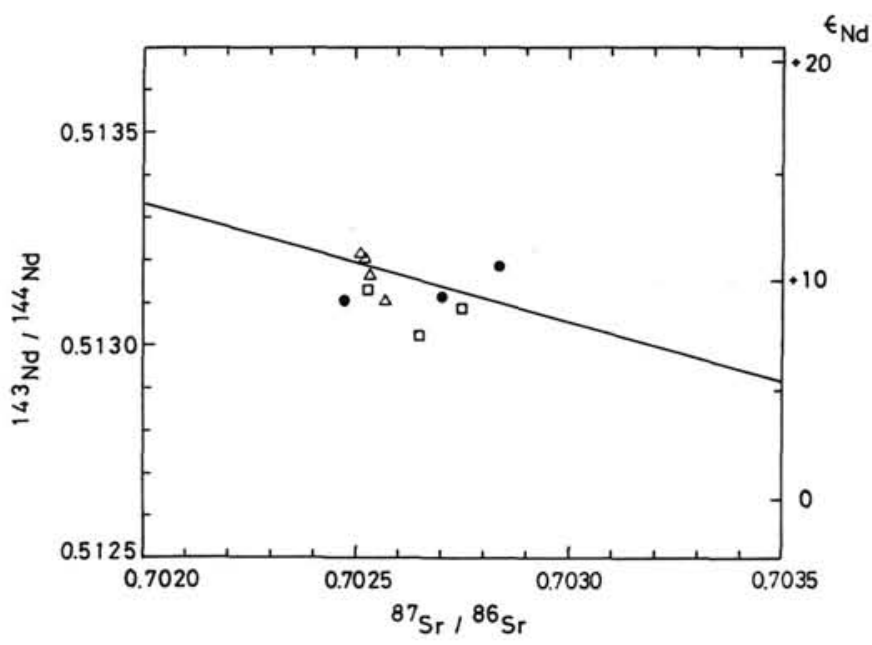

Figure $5 .{ }^{143} \mathrm{Nd} /{ }^{144} \mathrm{Nd}$ vs. ${ }^{87} \mathrm{Sr} /{ }^{86} \mathrm{Sr}$ for Pacific Ocean MORB. Squares = Juan de Fuca Ridge, Galapagos Ridge, and East Pacific Rise (Cohen et al., 1980); triangles = East Pacific Rise (White and Hofmann, 1982); solid circles $=$ Hole 504B (this study). The line shows the trend for MORB.

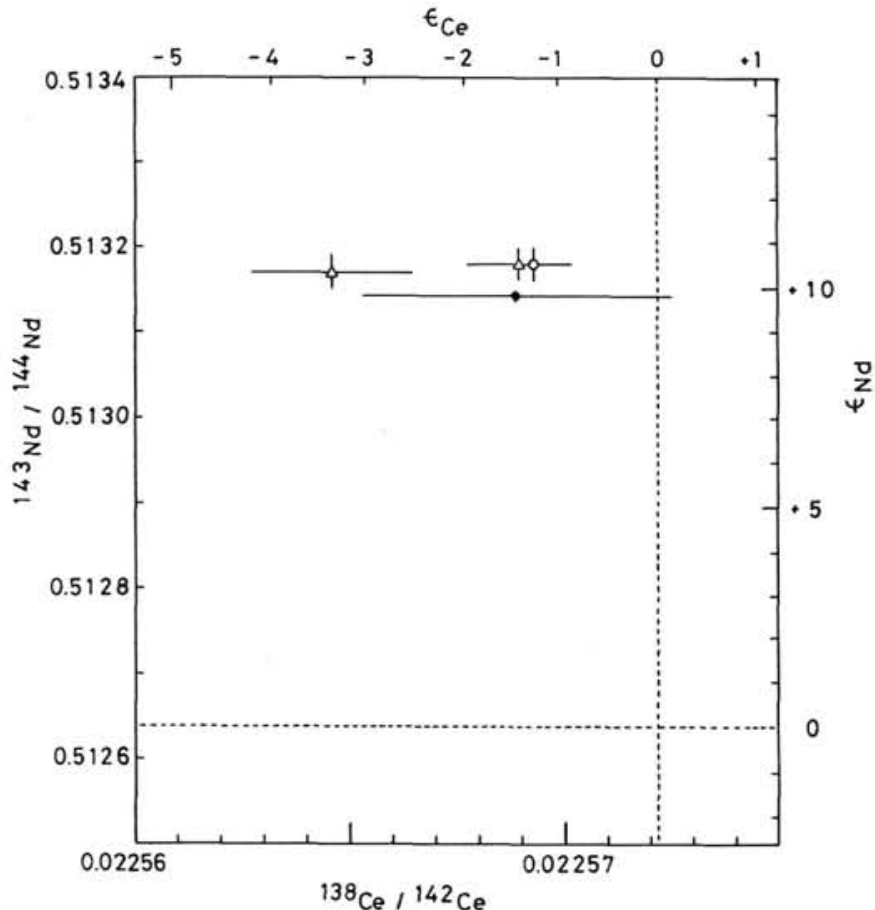

Figure 6. ${ }^{143} \mathrm{Nd} /{ }^{144} \mathrm{Nd}$ vs. ${ }^{138} \mathrm{Ce} /{ }^{142} \mathrm{Ce}$ for MORB. Solid circle $=$ Hole 504B basalt (this study); open circle = basalt from East Pacific Rise $\left(12^{\circ} 52^{\prime} \mathrm{S}, 110^{\circ} 57^{\prime} \mathrm{W}\right.$; Tanaka et al., 1987); open triangles = basalts from Mid-Atlantic Ridge $\left(22^{\circ} 59.14^{\prime} \mathrm{N}, 43^{\circ} 30.90^{\prime} \mathrm{W}\right.$ and $23^{\circ} 02.63^{\prime} \mathrm{N}$, $45^{\circ} 01.05^{\prime} \mathrm{W}$; Tanaka et al., 1987). $\epsilon=\left(\left[\mathrm{R}_{\text {sample }}-\mathrm{R}_{\mathrm{CHUR}}\right] / \mathrm{R}_{\mathrm{CHUR}}\right) \times$ $10^{4}$, where $R_{\text {sample }}$ is the sample isotopic ratios ${ }^{143} \mathrm{Nd} /{ }^{144} \mathrm{Nd}$ or ${ }^{138} \mathrm{Ce} /$ ${ }^{142} \mathrm{Ce}$ and $\mathrm{R}_{\mathrm{CHUR}}$ is chondritic uniform reservoir. Present-day values of $\left({ }^{143} \mathrm{Nd} /{ }^{144} \mathrm{Nd}\right)_{\mathrm{CHUR}}$ and $\left({ }^{138} \mathrm{Ce} /{ }^{142} \mathrm{Ce}\right)_{\mathrm{CHUR}}$ are 0.512638 (Wasserburg et al., 1981) and 0.0225722 (Shimizu et al., 1984, 1988), respectively.

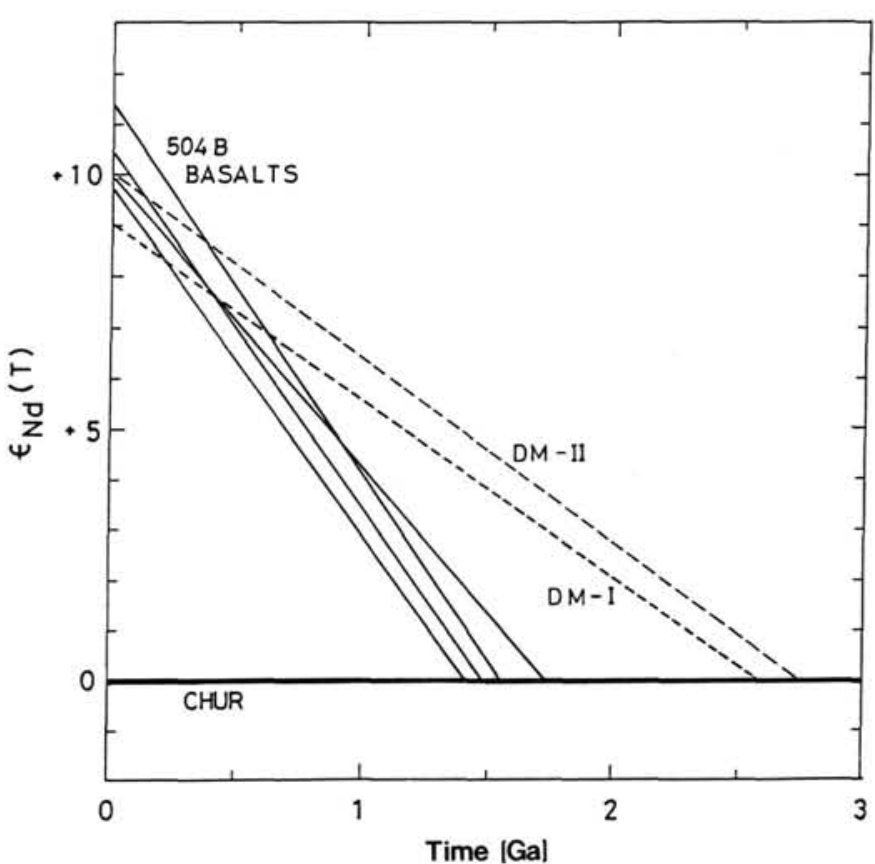

Figure 7. Isotopic evolution of Nd in average MORB (dashed lines) and Hole 504B basalts (solid lines) (see text and Table 5). Depleted mantle A $(D M-A)$ has present-day values of ${ }^{143} \mathrm{Nd} /{ }^{144} \mathrm{Nd}=0.5131\left(\epsilon_{\mathrm{Nd}}=+9.0\right)$ and ${ }^{147} \mathrm{Sm} /{ }^{144} \mathrm{Nd}=0.2238$ (Hawkesworth and van Calsteren, 1984). Depleted mantle B (DM-B) has present-day values of ${ }^{143} \mathrm{Nd} /{ }^{144} \mathrm{Nd}=$ $0.513153\left(\epsilon_{\mathrm{Nd}}=+10.0\right)$ and ${ }^{147} \mathrm{Sm} /{ }^{144} \mathrm{Nd}=0.225$ (Liew and McCulloch, 1985). CHUR (horizontal line) present-day values are ${ }^{143} \mathrm{Nd} /{ }^{144} \mathrm{Nd}$ $=0.512638$ and ${ }^{147} \mathrm{Sm} /{ }^{144} \mathrm{Nd}=0.1966$ (Wasserburg et al., 1981). $\epsilon_{\mathrm{Nd}}(\mathrm{T})=\left(\left[\mathrm{R}_{\text {sample }}(\mathrm{T})-\mathrm{R}_{\mathrm{CHUR}}(\mathrm{T})\right] / \mathrm{R}_{\mathrm{CHUR}}(\mathrm{T})\right) \times 10^{4} ; \mathrm{R}(\mathrm{T})={ }^{143} \mathrm{Nd} /$ ${ }^{144} \mathrm{Nd}$ at time $\mathrm{T}$.

Table 5. Nd model ages for chondritic uniform reservoir (CHUR) and depleted mantle (DM-A and DM-B).

\begin{tabular}{lccc}
\hline $\begin{array}{c}\text { Core, section, } \\
\text { interval (cm) }\end{array}$ & CHUR $^{\mathrm{a}}$ & DM-A $^{\mathrm{b}}$ & DM-B $^{\mathrm{c}}$ \\
\hline $143 \mathrm{R}-1,22-24$ & $1.47 \times 10^{9}$ & $0.409 \times 10^{9}$ & $0.129 \times 10^{9}$ \\
$145 \mathrm{R}-2,62-64$ & $1.41 \times 10^{9}$ & $0.212 \times 10^{9}$ & - \\
$148 \mathrm{R}-1,83-88$ & $1.72 \times 10^{9}$ & $0.424 \times 10^{9}$ & - \\
$163 \mathrm{R}-2,29-31$ & $1.55 \times 10^{9}$ & $0.618 \times 10^{9}$ & $0.365 \times 10^{9}$ \\
\hline
\end{tabular}

Note: In calculating $\mathrm{Nd}$ model ages, the $\mathrm{Nd}$ isotopic ratios of the Hole 504B basalts are corrected by normalization of ${ }^{143} \mathrm{Nd} /{ }^{144} \mathrm{Nd}=0.511858$ for the La Jolla Nd standard. $\lambda_{\alpha}{ }^{147} \mathrm{Sm}=6.54 \times 10^{-12} / \mathrm{yr}$.

a Present-day parameters: ${ }^{143} \mathrm{Nd} /{ }^{144} \mathrm{Nd}=0.512638$ and ${ }^{147} \mathrm{Sm} /{ }^{144} \mathrm{Nd}=0.1966$ (Wasserburg et al., 1981).

b Present-day parameters: ${ }^{143} \mathrm{Nd} /{ }^{144} \mathrm{Nd}=0.5131\left(\epsilon_{\mathrm{Nd}}=\right.$ +9.0 ) and ${ }^{147} \mathrm{Sm} /{ }^{144} \mathrm{Nd}=0.2238$ (Hawkesworth and van Calsteren, 1984).

c Present-day parameters: ${ }^{143} \mathrm{Nd} /{ }^{144} \mathrm{Nd}=0.513153\left(\epsilon_{\mathrm{Nd}}=\right.$ +10.0 ) and ${ }^{147} \mathrm{Sm} /{ }^{144} \mathrm{Nd}=0.225$ (Liew and McCulloch, 1985). 